\title{
Sequence-, Tissue-, and Delivery-Specific Targeting of RNA During Post-Transcriptional Gene Silencing
}

\author{
Ezequiel Balmori-Melian, ${ }^{1,2}$ Robin M. MacDiarmid, ${ }^{1}$ David L. Beck, ${ }^{1}$ Richard C. Gardner, ${ }^{2}$ and \\ Richard L. S. Forster ${ }^{1}$ \\ ${ }^{1}$ The Horticulture and Food Research Institute of New Zealand Limited, Private Bag 92169 Auckland, New Zealand; \\ ${ }^{2}$ University of Auckland, Private Bag 92019 Auckland, New Zealand
}

Submitted 14 June 2001. Accepted 27 March 2002.

\begin{abstract}
Transgenic Nicotiana benthamiana plants expressing an untranslatable version of the coat protein (CP) gene from the Tamarillo mosaic virus (TaMV) were either resistant to TaMV infection or recovered from infection. These phenotypes were the result of a post-transcriptional gene silencing (PTGS) mechanism that targeted TaMV-CP sequences for degradation. The TaMV-CP sequences were degraded when present in the wild-type TaMV potyvirus, in transgene mRNA, or in chimeric viral vectors based on White clover mosaic virus. The more efficiently targeted region was mapped to a 134-nt segment. Differences were observed in the efficiency of targeting during cell-to-cell and long-distance movement of the chimeric viruses. However, the TaMV-CP sequences do not appear to be targeted for degradation when delivered by biolistics.
\end{abstract}

Additional keywords: RT-PCR, transgenic plants, viral replication.

Post-transcriptional gene silencing (PTGS), also known as quelling or RNA interference (RNAi), appears to be a cellular defense mechanism against viruses and transposable elements that is present in different organisms (Marx 2000; Sijen and Kooter 2000). Induction of PTGS can be activated by doublestranded RNA and results in sequence-specific degradation of cellular RNAs (Baulcombe 1999; Kooter et al. 1999). During PTGS, the target mRNA is cleaved at 21- to 25-nt intervals (Hamilton and Baulcombe 1999; Zamore et al. 2000) by a nuclease of the RNAse III family (Bernstein et al. 2001).

Initially, PTGS was observed in plants when the introduction of a chimeric copy of an endogenous gene induced suppression of expression of the chimeric and the homologous endogenous gene (Napoli et al. 1990; van der Krol et al. 1990). In addition, plants expressing potyviral transgenes showed resistance to viral infection by the corresponding potyvirus. In these transgenic plants, the transgene caused suppression of its own expression as well as a block in accumulation of homologous viruses (Dougherty et al. 1994; Lindbo and Dougherty 1992a; Lindbo et al. 1993; Smith et al. 1994). The post-transcriptional nature of this type of suppression was demonstrated by nuclear run-off experiments (de Carvalho et al. 1992; Dougherty et al. 1994; Mueller et al. 1995). Steady state levels of targeted mRNAs were strongly reduced while the transcription levels of targeted genes in the nucleus were comparable to

Corresponding author: R. C. Gardner, E-mail: r.gardner@auckland.ac.nz

Current address of R. L. S. Forster: Genesis Research and Development Corporation Ltd, PO Box 50, Auckland, New Zealand. or higher than those found in nonsilenced tissues. In some cases, transgenic plants expressing potyviral genes were not resistant to infection, but showed a phenotype known as recovery (Dougherty et al. 1994). These plants initially showed viral symptoms but PTGS was subsequently induced so that the uninoculated upper regions of the plants became resistant to infection by the virus.

It is clear that the degradation machinery during PTGS acts against viral replication, because individual protoplasts from transgenic plants show viral resistance (English et al. 1996; Lindbo et al. 1993; Longstaff et al. 1993; Sijen et al. 1995, 1996). It is also clear that PTGS is composed of different stages: initiation, spread, and maintenance; and that a silencing signal is able to move systemically throughout the plant (Palauqui and Balzergue 1999; Palauqui et al. 1997; Vaucheret et al. 1997; Voinnet et al. 1998). During a normal viral infection, a PTGS signal against the virus is induced and it is likely that there is competition between the spread of the virus and the spread of the silencing signal (Voinnet et al. 1998). Accordingly, viral genes have evolved to block different stages of the PTGS process (Anandalakshmi et al. 1998; Kasschau and Carrington 1998; Mallory et al. 2001; Voinnet et al. 1999, 2000).

We are studying PTGS using Tamarillo mosaic virus (TaMV), a strain of Potato virus A (PVA) that shows the typical characteristics of the potyvirus group (Dougherty and Carrington 1988; Eagles et al. 1990; Mossop 1977; Puurand et al. 1994). A series of transgenic lines of Nicotiana benthamiana were constructed that express untranslatable TaMV coat protein $(\mathrm{CP})$ transcripts. We describe here the study of one transgenic line of plants containing an untranslatable version of the TaMV-CP gene and demonstrate that a PTGS mechanism is occurring in this line. The plants showed either recovery or resistant phenotypes when challenged with TaMV. Using a heterologous virus, White clover mosaic virus (WCIMV), containing regions of the TaMV-CP gene, we show that more than one region of TaMV-CP sequences is targeted and that the efficiency of targeting different regions varies. We also conclude that PTGS affects local movement of the virus less than systemic movement. Moreover, the efficiency of degradation of the targeted sequences depended on the way that the sequences were delivered into the plant cells.

\section{RESULTS}

A WCIMV-based viral vector efficiently carries foreign sequences.

The viral construct $7 \mathrm{~K}^{*}$ was designed so that foreign sequences could be introduced into a multiple cloning site 
(MCS) upstream of the CP gene in a full-length infectious clone of WClMV (Fig. 1A). Polymerase chain reaction (PCR) fragments containing $\mathrm{CP}$ sequences from the TaMV strain of the potyvirus PVA were introduced into the MCS of $7 \mathrm{~K}^{*}$. A series of chimeric $7 \mathrm{~K}^{*}$ virus clones was generated carrying sections of the CP gene of TaMV (W-TaMV\#1 through WTaMV\#6, and W-TaMV full, Fig. 1B). The vector $7 \mathrm{~K}^{*}$ does not contain duplicated subgenomic promoters, so that the inserted sequences are transcribed only as part of the normal viral genomic RNA and large subgenomic RNA.

In vitro transcripts from the clones were inoculated onto wild-type $N$. benthamiana plants. Total RNA from the upper leaves of the infected plants was tested for the presence of viral RNA 20 days postinoculation (dpi) by northern analysis using a TaMV-CP probe. The chimeric viral transcripts infected the plants systemically and the viral progeny contained the inserted sequences (Fig. 2A). Reverse transcriptase (RT)-PCR was performed to characterize the stability of the foreign sequences in the viral vectors at $60 \mathrm{dpi}$, using primers flanking the insertion site (Fig. 1A). The inserted fragments of TaMV mostly were retained in the WCIMV vector at 60 dpi (Fig. 2B). However, in the case of the construct carrying the full-length $\mathrm{CP}$ gene, the viral progeny was a mix of populations that contained the full-length inserts or had partially or totally lost the inserted sequences (data not shown).

These results demonstrated that most of the potyviral CP sequences were stably maintained in most copies of the chimeric WClMV-based viruses during prolonged systemic infection in N. benthamiana.

\section{TaMV-CP sequences are post-transcriptionally targeted for degradation in transgenic plants.}

Transgenic $N$. benthamiana plants expressing an untranslatable version of the TaMV-CP gene were obtained by Agrobacterium-mediated transformation. Progeny (T1) from 31 primary transformants were challenged with TaMV. Two phenotypes were observed, typical of other reports of potyviral gene silencing (Lindbo and Dougherty 1992a, b; Lindbo et al. 1993). The first class of transgenic lines were resistant to TaMV infection, as determined by the lack of systemic symptoms and northern analysis of the resistant leaves (Fig. 3A and data not shown). The second class initially displayed a normal TaMV infection but subsequent emerging leaves were free from the virus. Northern analysis of these plants showed high levels of transgene TaMV-CP mRNA in infected leaves but nondetectable levels in the upper recovered leaves (Fig. 3A). Enzyme-linked immunosorbent assay (ELISA) and sap inocu-
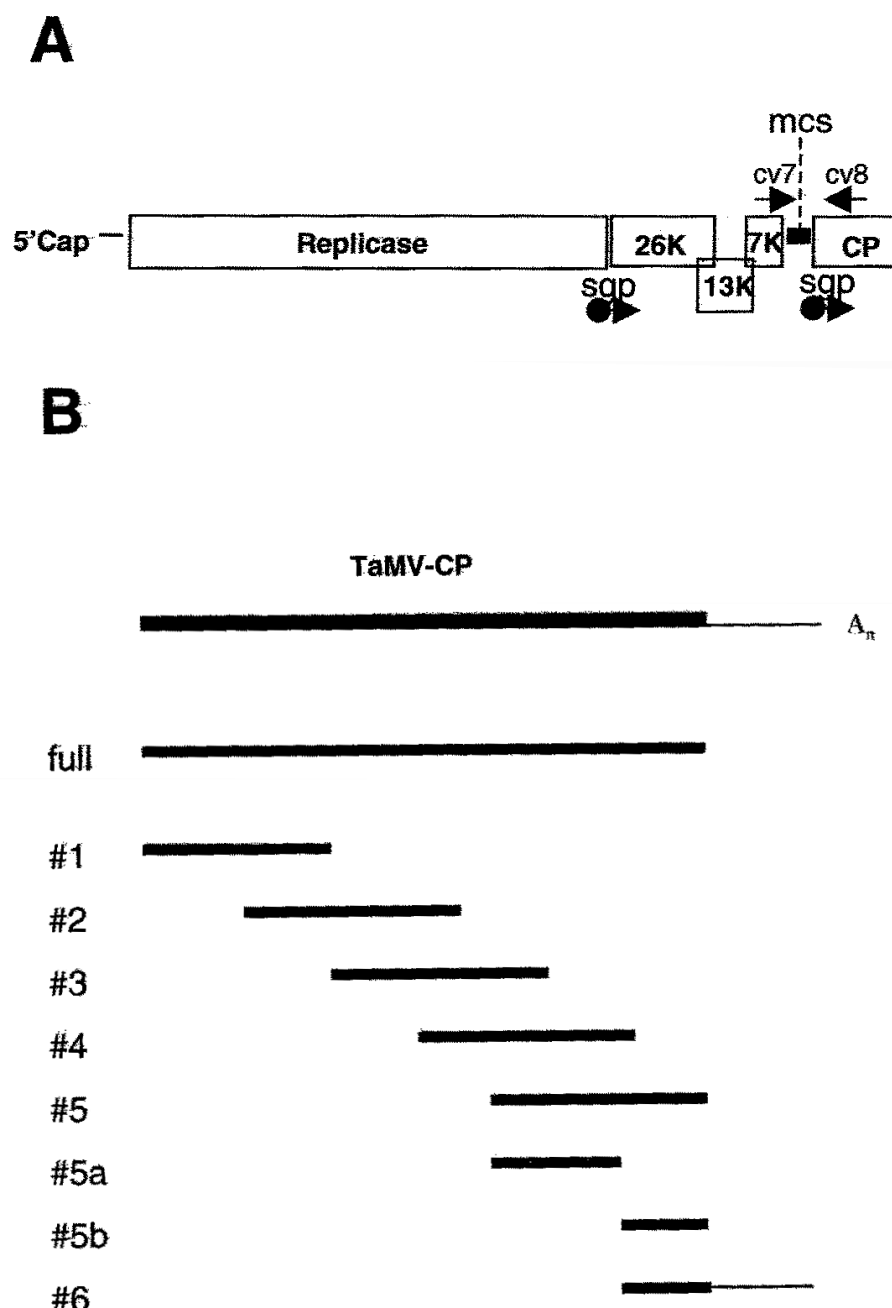

Fig. 1. W-TaMV constructs in the White clover mosaic virus (WCIMV)-based viral vector $7 \mathrm{~K}^{*}$. A, The $7 \mathrm{~K}^{*}$ viral vector used for delivering foreign sequences into Nicotiana benthamiana plants. Open reading frames in the WCIMV genome are indicated by rectangles (replicase, triple gene block proteins of 26,13 , and $7 \mathrm{kDa}$ and the coat protein $[\mathrm{CP}]$ ), and subgenomic promoters are indicated by arrows above the genome. The CP sequences of Tamarillo mosaic virus (TaMV) were inserted in the multiple cloning site (MCS) of $7 \mathrm{~K}^{*}$. Primers CV7 and CV8 were used to amplify inserts in infected plants. B, Different fragments of the TaMV-CP gene were inserted at the MCS between the 7K and the CP gene. The clones contain the indicated regions of the TaMV-CP gene, with the $3^{\prime}$ untranslated region included in fragment \#6. Note that the full, \#1, and \#5 fragments also were inserted into the plant vector for biolistic studies. 
lation confirmed the lack of virus in the recovered tissue (data not shown). This phenotype will be referred to as RAT (recovery at top). The reduced accumulation of TaMV-CP sequences in recovered tissue was post-transcriptional, because nuclear run-off experiments showed that the accumulation of transgene mRNA in the nuclei was similar in infected and recovered tissue (Fig. 3B).

Second generation $\mathrm{T} 2$ progeny were obtained from a singleinsert transgenic line that showed the RAT phenotype. Some T2 plants were completely resistant to TaMV infection, and kanamycin inheritance ratios showed that these resistant plants were homozygous for the transgenic insertion. One of these homozygous resistant lines, II-R, was used for further experiments. All the progeny (50/50) from the II-R resistant line also were resistant to TaMV. Northern hybridization was unable to detect transgene mRNA in the leaves of any of the II-R resistant plants (Fig. 3A).

\section{Inoculated leaves from resistant plants are not immune to all W-TaMV chimeric constructs.}

To test which part of the TaMV-CP gene was targeted for degradation in the II-R line, plants were inoculated with transcripts from W-TaMV\#1 to W-TaMV\#5 and analyzed for the presence of viral progeny. An ELISA-test, with antibodies raised against the WCIMV $\mathrm{CP}$, was performed using equal amounts of tissue from the inoculated and upper leaves at 7 and $21 \mathrm{dpi}$, respectively. Samples were assessed as infected or noninfected based on their ELISA readings (Table 1). Our observations for the inoculated leaves are considered in this section, and the systemic results will be analyzed below.

Transcripts from W-TaMV-full efficiently replicated in the inoculated leaves of the nontransgenic control plants but were unable to establish an infection in the inoculated leaves of the resistant plants (Table 1, first line) (Fig. 4A). Vectors containing different regions of the TaMV CP behaved differently. Four of the chimeric viruses carrying 300-nt fragments of the TaMVCP gene (W-TaMV\#1 to W-TaMV\#4) were able to accumulate in a high proportion (44 to $94 \%$ ) of the II-R inoculated leaves (Table 1). In contrast, the W-TaMV\#5 chimeric virus containing the 3'-most fragment of the TaMV CP gene accumulated in only $5.5 \%$ of the inoculated II-R plants (Table 1).

Among II-R plants that became infected, the accumulation of WCIMV CP in inoculated leaves infected with W-TaMV\#1, $\mathrm{W}-\mathrm{TaMV} \# 2$, and W-TaMV\#3 was high, comparable to the levels reached in the nontransgenic controls or the levels reached by WCIMV in transgenic lines (Fig. 4A). In contrast, lower levels of $\mathrm{CP}$ were detected in the inoculated leaves of II-R plants infected with W-TaMV\#4 and W-TaMV\#5 (Fig. 4A). One plant inoculated with W-TaMV\#5 exhibited high levels of WCIMV CP but further RT-PCR analysis showed that the TaMV sequence in this virus had been deleted. These results indicate that the $3^{\prime}$ region of the TaMV-CP gene contains the preferred target or targets during PTGS in the inoculated leaves.

\section{Upper systemic leaves of the resistant plants are immune to infection with W-TaMV constructs.}

The ELISA test was performed in the upper leaves of the same inoculated plants $21 \mathrm{dpi}$. In the case of WCIMV, the infection of the upper leaves was similarly efficient in the II-R and nontransgenic controls (Fig. 4A and B). In contrast, WTaMV-full virus was detected in only one II-R plant. This plant had shown no infection in the inoculated leaf; therefore, RT-PCR was performed and the plant was shown to contain a viral population lacking the inserted TaMV-CP sequence (data not shown). This plant, therefore, was categorized as uninfected in Table 1 and Fig. 4B.
Viral progeny of W-TaMV\#1 were detected in the upper leaves of $78 \%$ of the resistant plants and viral levels in these infected upper leaves were similar to those in inoculated leaves (Table 1; Fig. 4A and B). These data demonstrate that there is little selection against the $5^{\prime}$-most 300-nt sequence of TaMV-CP when delivered as a W-TaMV chimeric virus.

Surprisingly, progeny from the W-TaMV\#2, W-TaMV\#3, and $\mathrm{W}-\mathrm{TaMV} \# 4$ chimeric viruses were detected systemically in only a low percentage of the II-R inoculated plants $(17,17$, and $5.5 \%$, respectively; Table 1). Numerous individual II-R plants that were found to accumulate high levels of these viruses in the inoculated leaves failed to do so in the upper leaves (Fig. 4B). However, in those few II-R plants that did become systemically infected by W-TaMV\#2, W-TaMV\#3, and $\mathrm{W}-\mathrm{TaMV} \# 4$, these viruses reached levels comparable to those in inoculated leaves (Fig. 4A and B). As in the inoculated leaves, W-TaMV\#5 was unable to break the resistance at the systemic level (Table 1).

In summary, we found significant differences between the infectivity of the various W-TaMV chimeric viruses in the inoculated and the systemic leaves. In particular, W-TaMV\#2, \#3, and \#4 were relatively inefficient in establishing viral infection in the upper leaves of most II-R plants compared with their results in inoculated leaves.

A

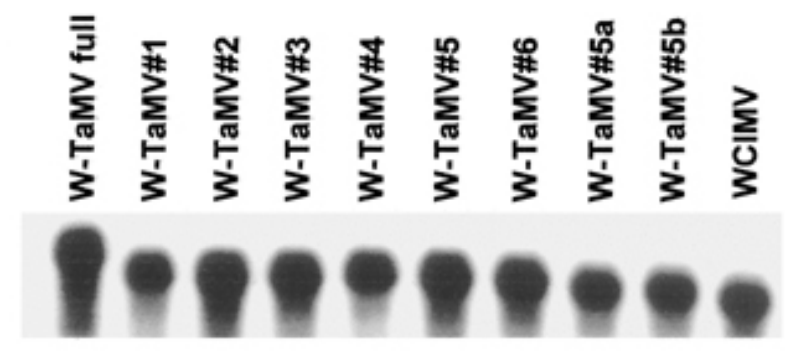

B

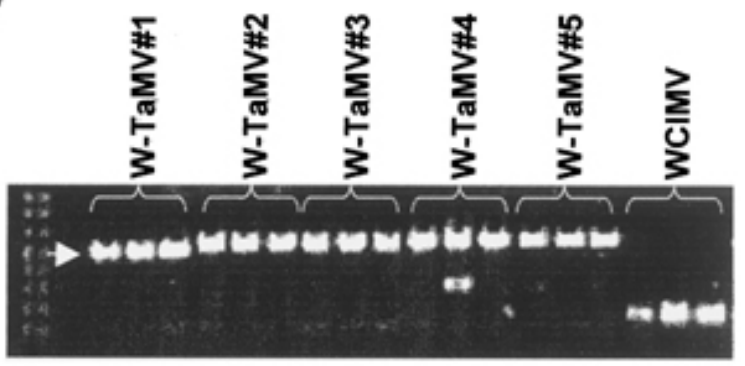

Fig. 2. Potyviral coat protein $(\mathrm{CP})$ fragments are maintained during systemic infection of a White clover mosaic virus (WClMV)-based vector. A, Northern analysis of total RNA from the upper leaves of plants inoculated with W-TaMV chimeric viruses. Total RNA extraction was performed 20 days postinoculation (dpi) and the genomic viral RNA is shown after hybridization with a Tamarillo mosaic virus (TaMV) CP-specific probe (except WCIMV lane, which was probed with a WClMV-CP-specific probe). B, Reverse transcriptase polymerase chain reaction (RT-PCR) was performed on poly-A RNA extracted from infected plants 60 dpi using the CV7/CV8 oligonucleotide pair. The white arrow indicates the expected size of the PCR product for the viral progeny containing the respective full-length inserts. 
Targeting in the resistant-plants appears complete.

In our hands, the ELISA test was not as sensitive as RT-PCR for the detection of viral progeny. Moreover, RT-PCR allows assessment of the stability of the insert. II-R plants inoculated with W-TaMV\#1 (positive by ELISA) or W-TaMV\#5 (negative by ELISA) were tested for the presence of virus by RTPCR using the primer pair CV7/CV8. Samples were taken 30 dpi from different leaves of two different II-R plants and one nontransgenic control plant per construct. The PCR products clearly showed that $\mathrm{W}-\mathrm{TaMV \# 1}$ progeny were present in most

A

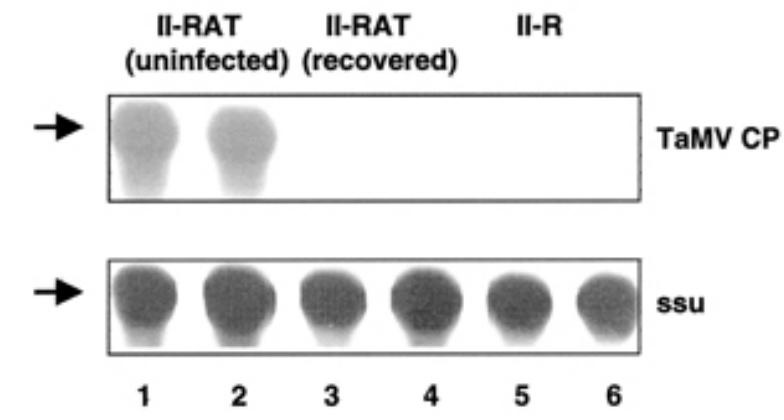

B

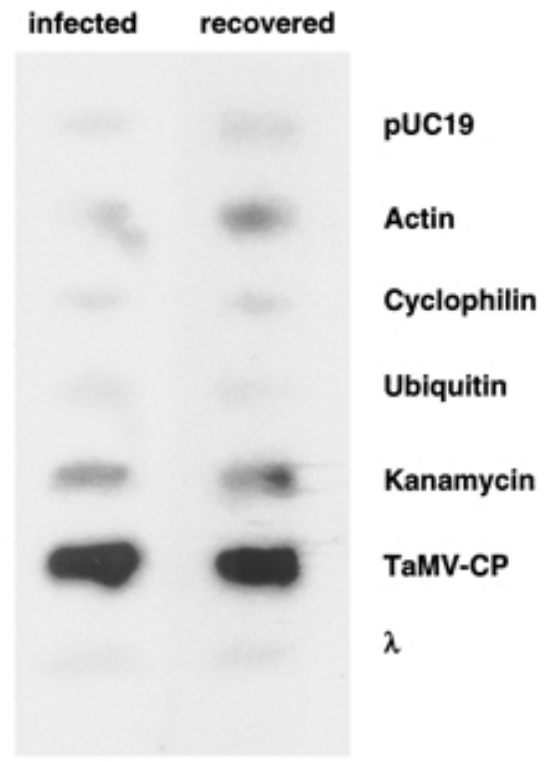

Fig. 3. Post-transcriptional gene silencing occurring in Tamarillo mosaic virus coat protein (TaMV-CP) transgenic plants. A, Northern analysis of total RNA from leaves of four T2 individuals (II-RAT), two showing the recovery phenotype (lanes $1-4$ ) and two resistant plants (II-R) (lanes 5 and 6). The blot was probed with a TaMV-CP-specific fragment. The arrows indicate the expected size of the transgenic TaMV-CP mRNA and the small subunit of ribulose 1,5-biphosphate carboxylase (ssu) RNA (as loading control). B, Nuclear run-off showing the transcription levels of the transgene in infected and recovered leaves from II-RAT plants that showed the recovery phenotype after infection with TaMV. The control probes used included pUC19 and bacteriophage lambda (as unrelated DNA controls), actin, cyclophilin and ubiquitin genes, and the two transgenes (kanamycin and TaMV-CP). leaves in both the resistant and nontransgenic plants (Fig. 5A), whereas W-TaMV\#5 was detected in leaves from the nontransgenic inoculated plants but not the resistant plants (Fig. 5B). These results confirmed that, in the resistant plants, the target TaMV-CP sequences are reduced to very low or undetectable levels.

\section{A 134-nt sequence is the best target for degradation in the resistant-plants.}

To determine more specifically the region within WTaMV\#5 that was targeted for degradation in the II-R plants, we constructed three additional viral vectors. W-TaMV\#5a contains the $5^{\prime}$-most $194 \mathrm{nt}$ and W-TaMV\#5b the remaining $134 \mathrm{nt}$ of the original W-TaMV\#5 insert (Fig. 1). Construct WTaMV\#6 contains the same TaMV sequences as W-TaMV\#5b, with 226 extra nucleotides of the untranslatable (UT)-3' region from the wild type-TaMV-CP. This UT-3' region is not present in the II-R transgenic line.

Transcripts from the three new constructs were inoculated into II-R plants and nontransgenic controls. The results of at least two independent experiments with each viral vector are summarized in the lower half of Table 1 . In $70 \%$ of the inoculated II-R plants, CP of the virus W-TaMV\#5a accumulated in the inoculated leaves to levels similar to those reached in the nontransgenic controls (Table 1; Fig. 4C). In contrast, WTaMV\#5b showed no accumulation of CP, while W-TaMV\#6 accumulated in only 2 of 30 inoculated II-R plants (Table 1). In the II-R-inoculated leaves in which $\mathrm{W}$-TaMV\#6 virus was detected, the viral accumulation was generally low, with ELISA readings less than half of the nontransgenic control readings (Fig. 4C).

Analysis of the upper leaves of the plants again showed some differences to the inoculated leaves. Systemic movement of W-TaMV\#5a was detected in only $4(13 \%)$ of the plants infected, despite the fact that 21 plants $(70 \%)$ had shown replication of the virus in the inoculated leaves (Table 1). However, in those plants judged to be systemically infected, CP titers were significantly reduced (Fig. 4D). As expected from their low infectivity in inoculated leaves, W-TaMV\#5b and WTaMV\#6 progeny seldom were detected in the upper leaves of the II-R plants ( 0 and $7 \%$, Table 1$)$ and the viral accumulation remained low (Fig. 4D). As was the case for W-TaMVfull described above, viral accumulation of W-TaMV\#6 was high in one plant that had shown no replication in the inoculated leaf. RT-PCR analysis detected a mixed population, where a large fraction of the progeny did not contain the inserted sequence (data not shown). This plant was again excluded from the analysis.

These results have shown that the region of the $\mathrm{CP}$ gene that is most strongly targeted by PTGS maps to a 134-bp segment at the very $3^{\prime}$ end of the TaMV CP gene. Possession of this region was sufficient to induce a strong inhibition of replication for both W-TaMV\#5b and W-TaMV\#6. In addition, the results for W-TaMV\#5a provided further evidence for greater targeting during systemic movement than in the inoculated leaves.

\section{Target sequences were not degraded when delivered by biolistics.}

Particle bombardment has been successfully used for the characterization of target sequences during gene silencing (Angell and Baulcombe 1997; Hobbs et al. 1993; Marano and Baulcombe 1998). This technique allows identification of the strand polarity of the targeted RNA, as well testing the sequence specificity.

Different regions of the TaMV-CP gene were introduced into a 35S-GUS vector, pART8 (Gleave 1992), downstream of the GUS-gene (Fig. 6A). The clones (pART8-full-sense, pART8- 
\#1-sense, pART8-\#5-sense, and pART8-\#5-antisense) carry the same TaMV CP segments as the corresponding WCIMV vectors (Fig 1B) in the indicated orientations. Whole leaves from young (12 to $15 \mathrm{~cm}$ tall) II-R and nontransgenic plants were bombarded with DNA of the constructs shown in Figure 6A and stained with X-gluc (Hobbs et al. 1993). To our surprise, there was no obvious difference in the number of GUSexpressing spots between the resistant and nontransgenic plants bombarded with any of the constructs (Fig. 6B). For example, pART8-TaMV-full produced numerous blue spots in resistant and nontransgenic plants. There was variation in the number of lesions per bombarded leaf but, overall, we observed no indication that GUS/TaMV-CP sequences were preferably targeted for degradation in the II-R plants. The experiments were repeated four times using a total of 40 leaves of the resistant plants and 20 leaves from the nontransgenic controls per DNA construct. In Figure 6B, we show a typical distribution of the GUS-expressing spots in the bombarded leaves. In one of the experiments, all the GUS-spots from leaves bombarded with pART8-TaMV-full sense and pART8 were counted. The construct pART8-TaMV-full sense produced on average approximately 830 and 700 blue spots in resistant and nontransgenic leaves, respectively, whereas pART8 induced the appearance of approximately 700 and 800 blue spots in the resistant and nontransgenic leaves, respectively. No GUS-expressing spots were detected in mock bombarded leaves of the resistant and nontransgenic plants (data not shown).

Taken together, these data indicate that GUS-TaMV-CP RNAs are not targeted for degradation when delivered by bombardment into II-R plants.

\section{DISCUSSION}

\section{Post-transcriptional silencing occurs in TaMV-CP transgenic plants.}

We have shown that PTGS is occurring in transgenic plants of $N$. benthamiana expressing the CP of TaMV. Plants with a single copy of the transgene expressed the transgene mRNA and were initially susceptible to infection with TaMV. Later in the infection, the new emerging leaves were devoid of TaMV and also were resistant to superinfection by TaMV (data not shown). In these newly emerged resistant leaves, there was a reduction in the steady levels of transgenic TaMV-CP mRNA (Fig. 3A) that was not a consequence of reduced transcription, because nuclei from infected and recovered tissue produced similar amounts of transgenic mRNA (Fig. 3B). This type of recovery was described for the first time for Tobacco etch virus, another potyvirus (Lindbo and Dougherty 1992b; Lindbo et al. 1993). In that case, the authors determined that the antiviral state in the recovered and resistant plants was virus specific and the result of a post-transcriptional degradation mechanism (Dougherty et al. 1994). Such a mechanism seems to be in place in our plants. Homozygous plants were derived from lines that showed the recovery phenotype; these plants (II-R) were resistant to TaMV infection and had low steadystate levels of transgene mRNA. WCIMV vectors carrying TaMV CP sequences also were inhibited from replicating in these plants, suggesting that PTGS is operative in the homozygous lines without the need for induction by TaMV infection.

\section{Different sequences of the TaMV-CP transgene are targeted for degradation with different efficiencies.}

We used a heterologous WCIMV vector to introduce RNA segments homologous to the transgene into the silenced plants to analyze the specificity of targeting in PTGS. Four conclusions can be drawn from the results. First there are clearly multiple targets in the TaMV CP gene. For example, fragments $\# 1, \# 3$, and \#5b are nonoverlapping segments of the gene that are all targeted to some extent in the II-R plants. Other researchers have previously reported that the targeted regions were distributed throughout the transgene sequence (Angell and Baulcombe 1997; Sonoda et al. 1999). Second, different fragments are targeted with different efficiencies (e.g., compare fragment \#1 and fragment \#5b). Third, there is a general trend in the data indicating that fragments toward the $3^{\prime}$ end of the CP gene are targeted more efficiently. The increase in the efficiency of targeting toward the $3^{\prime}$ end of the gene was not related to the size of the inserts because most chimeric constructs in this study contained inserts of approximately the same size (approximately $300 \mathrm{nt}$ ). Furthermore, an efficiently targeted construct, W-TaMV\#5b (Figs. 1B and 4C; Table 1), contained the smallest TaMV-CP gene insert (134 bp). Several groups have indicated previously that the $3^{\prime}$ end of mRNAs was the preferred target during PTGS (English et al. 1996; Sijen et al. 1996; Thompson et al. 1992). Within this gradient, however, certain specific sequences or structures may help to determine whether a region is targeted for degradation. Finally, the targeting can involve internal RNA sequences and likely involve endonucleolytic cleavage. Our viral vector, $7 \mathrm{~K}^{*}$, does not contain duplicated subgenomic promoters for the expression of the inserted sequences. This means that the target TaMV sequences are contained within the viral genomic RNA and within the large subgenomic RNA that expresses the triple

Table 1. Accumulation of W-TaMV constructs is inhibited in II-R plants ${ }^{\mathrm{a}}$

\begin{tabular}{|c|c|c|c|c|}
\hline \multirow[b]{2}{*}{ Constructs } & \multicolumn{2}{|c|}{ Inoculated leaves } & \multicolumn{2}{|c|}{ Systemic leaves } \\
\hline & $\#$ & $\%$ & $\#$ & $\%$ \\
\hline W-TaMV full & $0 / 18$ & (0) & $0 / 17$ & (0) \\
\hline W-TaMV\#1 & $17 / 18$ & $(94$ & $14 / 18$ & (78) \\
\hline W-TaMV\#2 & $17 / 18$ & (94) & $3 / 18$ & (17) \\
\hline W-TaMV\#3 & $13 / 18$ & (72) & $3 / 18$ & (17) \\
\hline W-TaMV\#4 & $8 / 18$ & (44) & $1 / 18$ & $(5.5)$ \\
\hline W-TaMV\#5 & $1 / 18$ & $(5.5)$ & $0 / 18$ & (0) \\
\hline Wild-type WCIMV & $18 / 18$ & $(100)$ & $17 / 17$ & $(100)$ \\
\hline W-TaMV\#5a & $21 / 30$ & (70) & $4 / 30$ & (13) \\
\hline W-TaMV\#5b & $0 / 20$ & (0) & $0 / 20$ & (0) \\
\hline W-TaMV\#6 (\#5b+ UT-3') & $2 / 30(7)$ & $1 / 29$ & (3.5) & \\
\hline Wild-type WCIMV & $28 / 30$ & (93) & $30 / 30$ & $(100)$ \\
\hline
\end{tabular}

${ }^{a}$ Resistant plants from the II-R line were inoculated with infectious transcripts of a White clover mosaic virus (WCIMV) vector containing parts of the coat protein gene of Tamarillo mosaic virus (TaMV). Samples were taken for enzyme-linked immunosorbent assay (ELISA) analysis 7 days postinoculation (dpi) from the inoculated leaves and $21 \mathrm{dpi}$ from the upper leaves of the plants and scored as either infected or uninfected. Combined ELISA results of at least two independent experiments are presented. Wild-type WCIMV was used as positive control of the inoculations. Results are expressed both as absolute number of infected plants per inoculated plants (\#) and as percentage of infected plants (\%). 
gene block proteins (Beck et al. 1991; Forster et al. 1992). The fact that we observed PTGS against these TaMV sequences implies that at least the first recognition and degradation event is targeted against internal sequences or secondary structures within the chimeric virus. Others have observed evidence of specific endonucleolytic cleavage inside the targeted region (Goodwin et al. 1996; Marano and Baulcombe 1998; Tanzer and Meagher 1994; Tanzer et al. 1997; Thomas et al. 2001).

\section{Differences between targeting}

in leaves and during systemic movement of the virus.

There was a significant increase in the degree of silencing between the inoculated leaves and the upper leaves of the plant. Significant differences were noted for all fragments in which silencing did not completely shut off replication of the virus in the lower leaves (i.e., fragments \#1, \#2, \#3, \#4, and \#5a; Table 1). In the case of fragments \#5 and \#6, a decrease was noted but it was not significant; and, for WClMV-containing fragment \#5b and the "full" CP gene, no comparison was possible because no progeny virus could be detected in the inoculated leaves. For some fragments, the difference was remarkable. For instance, 17 plants accumulated high levels of chi- meric W-TaMV\#2 in their inoculated leaves, but 14 of these 17 were devoid of virus in the upper parts of the plants (Table 1).

We did not find strong evidence for consistent differences in viral titers in the inoculated leaves compared with the upper leaves. In those plants in which the viruses W-TaMV\#1, WTaMV\#2, W-TaMV\#3, and W-TaMV\#6 managed to overcome the resistance to systemic movement, the $\mathrm{CP}$ accumulated in upper leaves to levels similar to those seen in the inoculated leaves (Fig. 4). There were some exceptions to this pattern, however, in which differences in the ELISA readings between upper and lower leaves were noted. For WTaMV\#5a, titers of $\mathrm{CP}$ were significantly higher in the inoculated leaves than in the upper leaves. It is possible that, in this case, the amount of virus entering the systemic leaves from the vasculature was very low, although the fact that the samples were taken very late in infection (40 dpi) was intended to overcome this problem. In two individual plants the opposite was found; there were low viral titers in inoculated leaves but very high titers in upper leaves. In both plants, the high titers correlated with recombination of the TaMV fragment out from the WCIMV vector (discussed above). It is possible that similar recombination events occurred in some other plants as well.
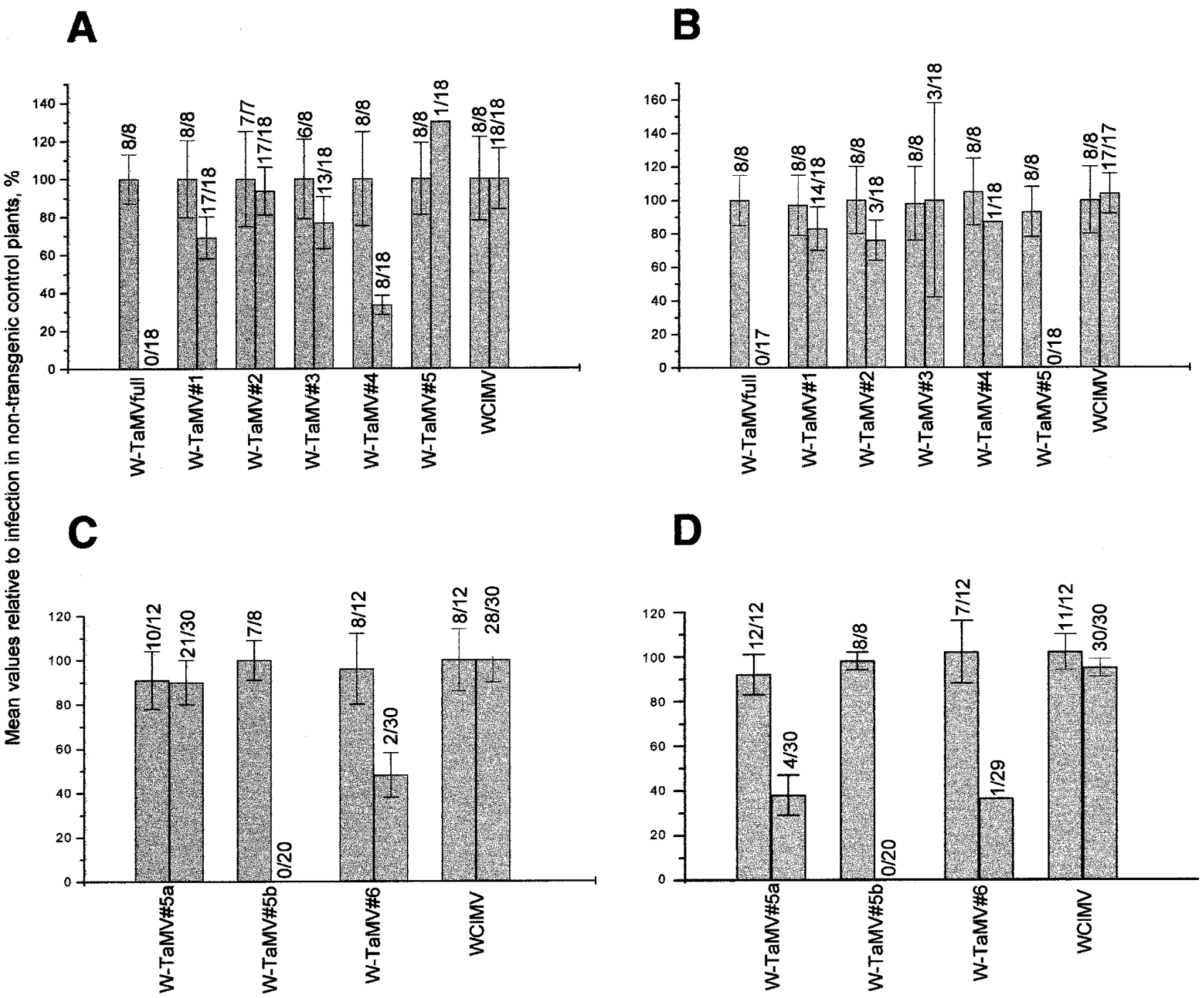

Fig. 4. Specific regions of the Tamarillo mosaic virus coat protein (TaMV-CP) gene are targeted differently in inoculated and upper leaves of the II-R plants. Nontransgenic plants were inoculated with infectious transcripts from W-TaMV chimeric viruses and White clover mosaic virus (WCIMV). The mean values of the positive enzyme-linked immunosorbent assay (ELISA) readings for each construct in nontransgenic and II-R plants are presented in pairs. The two columns represent the values in nontransgenic (left) and II-R plants (right). The number of plants showing positive ELISA readings are shown above each bar. Samples were taken A, C, 7 days postinoculation (dpi) from the inoculated leaves and $\mathbf{B}, \mathbf{D}, 28$ dpi from the upper leaves. 
Based on the differences between inoculated leaves and systemic leaves, we propose that there may be a difference in PTGS between leaves and the vascular system of our transgenic plants. A quantitative difference between the tissues would be sufficient to explain most features of the results here. Under this hypothesis, the same sequences would be targeted in both tissues, but the efficiency of targeting would be higher in vascular tissues.

Several factors could be responsible for an increase in level of PTGS in vascular cells of the transgenic plants. One is that the Cauliflower mosaic virus $35 \mathrm{~S}$ promoter used in this plant line is more efficient in roots and vascular tissues (Benfey and Chua 1989; Jefferson et al. 1987). Alternatively, it would not be surprising if vascular cells are inherently more capable of PTGS, given that the PTGS mechanism is proposed to be a defense system against viruses. For example, small RNAs, which are key components of the signaling and specificity machinery of PTGS (Dalmay et al. 2000; Hamilton and Baulcombe 1999; Palauqui et al. 1997; Voinnet and Baulcombe 1997; Voinnet et al. 1998), could be more abundant in the vascular tissue of the II-R plants.

Finally, a possibility remains that the apparent high efficiency of targeting in the vasculature is simply a result of the physical architecture of the plant and the pathway that viruses use to move throughout the plant. If systemic movement requires a large number of sequential steps, while cell-to-cell movement in a leaf offers many potential alternative steps, then a similar efficiency of targeting in each cell type may still result in a greater restriction overall on systemic movement. However, we believe that the late sampling (40 dpi) should have eliminated that possibility.

Specific inhibition of long-distance movement in resistant plants that target viral RNA has been reported for numerous systems (Canto and Palukaitis 1998; Carr et al. 1994; Hellwald and Palukaitis 1995; Iyer and Hall 2000; Longstaff et al. 1993; Sijen et al. 1996; Wintermantel et al. 1997). In the case of $\mathrm{Cu}$ cumber mosaic virus (CMV) replicase transgenic plants, Wintermantel and associates (1997) found restriction of viral movement into the vascular parenchyma and companion cells surrounding the sieve elements. A similar restriction of vascular entry was reported earlier for Cowpea chlorotic mottle virus in soybean and for the masked strain of Tobacco mosaic virus (TMV) in nontransgenic tobacco plants (Ding et al. 1995). However, neither these studies nor our present work differentiate between restriction of movement and active degradation of target RNA in the vascular tissue itself. Considering the PTGS character of the mechanism in place in our plants, we are inclined to favor a PTGS-based degradation mechanism in the vascular tissue.

Although a quantitative difference in PTGS in the two different tissues is sufficient to explain most of our observed results, it is also possible that qualitatively different target sequences for PTGS (or even different mechanisms of resistance altogether) are involved in the two different tissues. As a result of studies using replicase-mediated resistance against CMV, Hellwald and Palukaitis (1995) proposed previously that there are different mechanisms acting against viral replication and long-distance viral movement. Although PTGS was not demonstrated in these plants, it is a likely mechanism of the resistance. Recent results with transgenic plants expressing the $\mathrm{p} 2$ protein of Brome mosaic virus also suggest a difference between silencing in inoculated leaves compared with systemic movement (Iyer and Hall 2000). Further indirect evidence supporting the presence of different mechanisms of targeting during PTGS comes from the study of different inhibitors of PTGS expressed by different viral genomes that act at different stages or locations during PTGS (Brigneti et al. 1998; Voinnet et al. 1999, 2000).
Targeted sequences are not degraded during biolistic experiments.

The lack of PTGS seen following our bombardment experiments was surprising. None of the sequences tested seemed to be targeted for degradation, not even sequences that are clearly targeted for degradation when delivered in a WClMV-based viral vector. These results contradict earlier findings in which GUS, TMV, and Potato virus X (PVX) sequences introduced by biolistics, in similar constructs, were subjected to silencing (Angell and Baulcombe 1997; Hobbs et al. 1993; Marano and Baulcombe 1998). Previous biolistic experiments have shown that inhibition of expression of the targeted gene is not complete, even in plants with extremely strong silencing. For example, when a GUS gene is targeted, some GUS-expressing spots always were observed, albeit with lower numbers (Angell and Baulcombe 1997; Marano and Baulcombe 1998). It is possible that the amount of DNA used or the extent of the GUS staining in our experiments obscured any silencing that occurred. Also, our data do not rule out post-transcriptional processing or cryptic events that would remove the TaMV-CP sequences from the chimeric GUS-TaMV-CP, although we consider these events unlikely.

Many features of PTGS are not yet clear, and there are many published examples of data that cannot be interpreted under current models. In the case of transgenic plants resistant to the tobamovirus Pepper mild mottle virus, the authors found that plants resistant to the virus showed abundant accumulation of the viral-replicase transgene identical to sequences present in the targeted virus (Tenllado et al. 1995). In contrast, during virus-induced silencing of phytoene desaturase (PDS) by PVXPDS infection, the levels of endogenous PDS mRNA were

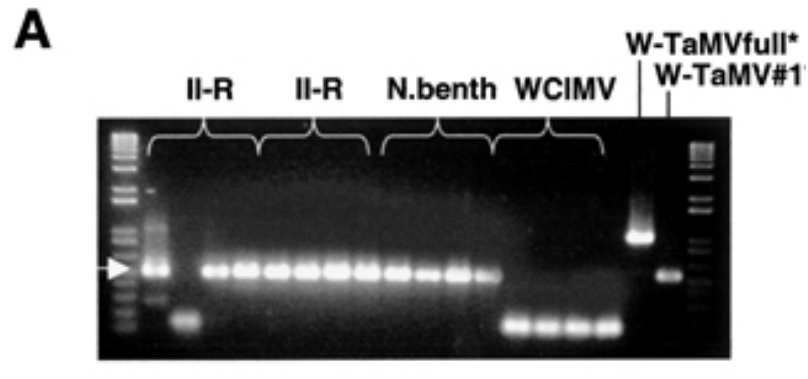

B

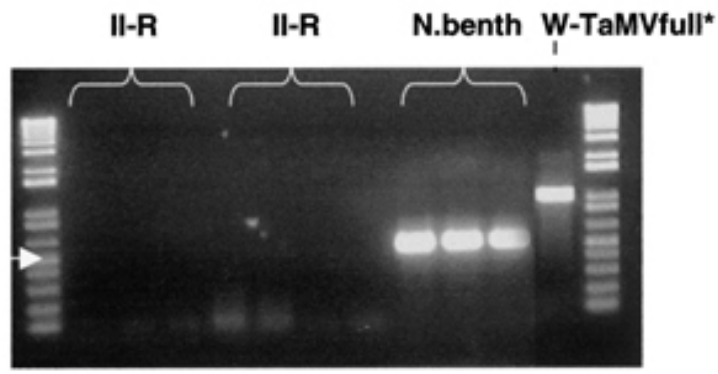

Fig. 5. Targeting of Tamarillo mosaic virus coat protein (TaMV-CP) sequences in the resistant plants appears complete. Plants from the transgenic line II-R were inoculated with infectious transcripts of $\mathbf{A}, \mathrm{W}$ TaMV\#1 or B, W-TaMV\#5. Reverse transcriptase polymerase chain reaction (RT-PCR) with the oligonucleotides CV7/CV8 was performed using poly-A RNA extracted from the upper leaves of inoculated plants 30 days postinoculation. Three or four samples were taken from each plant for analysis. The arrows indicate the expected size of the PCR fragments for viral progeny containing the full-length sequence of their respective inserts. Plasmid positive controls (*) were used for each experiment. 
heavily suppressed while PVX-PDS accumulated at high levels in PDS-silenced tissue (Ruiz et al. 1998). Likewise, Kjemtrup and colleagues reported that the silencing of a sulfur allele of magnesium chelatase (su) was not proportional to the accumulation of the virus that induced the silencing in the first place (Kjemtrup et al. 2000). In another case, plants that accumulated high levels of GUS transgenic mRNA and that were not activated for GUS-silencing were resistant to infection by PVX-GUS (English et al. 1997). Furthermore, transgenic plants expressing high levels of a phenylalanine ammonia lyase (PAL) transgene showed suppressed levels of the endogenous PAL genes (Elkind et al. 1990). More recent results showed that a targeted region from the RNA 2 of Brome mosaic virus was not targeted for degradation when carried within a chimeric RNA 3 molecule. In these plants, the replication of the same RNA 2 was inhibited (Iyer and Hall 2000). Similarly, transgenic resistance to $\mathrm{PVY}^{\circ}$ associated with posttranscriptional silencing of the P1 transgene was overcome by $\mathrm{PVY}^{\mathrm{n}}$, a strain with approximately $96 \%$ homology to $\mathrm{PVY}^{\circ}$ in the P1 gene (Maki-Valkama et al. 2000). Our biolistics results and reports discussed above may be an indication that the same sequences can be targeted differently, depending in their location in the cell or the role of specific contexts surrounding the sequences.

\section{MATERIALS AND METHODS}

\section{Generation of transgenic UTII plants.}

$N$. benthamiana were used for Agrobacterium-mediated transformation with a binary vector carrying an untranslatable version of the TaMV-CP. The TaMV-CP was amplified from a partial cDNA clone of TaMV (Eagles et al. 1990) by PCR using oligonucleotides RE14 (GCCGTCTCGAGGATCCATGGCCTAGGACCCTTGATGC) and RE15 (CGGCGAGCTCGGTACCTTACACCCCCTTCACGC) to incorporate an initiation start codon in a favorable context for translation (Lutcke et al. 1987) followed by three codons to terminate translation. Also, the amplified TaMV-CP product was thereby flanked with restriction enzyme sites incorporating XhoI, BamHI, and NcoI at the $5^{\prime}$ and KpnI at the $3^{\prime}$ ends. Following restriction with $X h o \mathrm{I}$ and $K p n \mathrm{I}$, the amplified TaMV-CP product was ligated into the same sites between the Cauliflower mosaic virus $35 \mathrm{~S}$ promoter and the octopine synthase $3^{\prime}$ transcription termination region within pART7 (Gleave 1992). The $35 \mathrm{~S}$ promoter-CP-terminator module within pART7 then was cleaved out with Not I digestion and ligated into the Not I site of pART27 (Gleave 1992), thus generating the binary vector UTII. Agrobacterium tumefaciens strain LBA4404 (Hoekema et al. 1983) was transformed with UTII and used to transform $N$. benthamiana leaf explants (Horsch et al. 1987). The $\mathrm{T}_{0}$ generation of UTII plants that regenerated on kanamycin $(100 \mathrm{mg}$ liter $^{-1}$ ) were transferred to soil and allowed to self-pollinate. $\mathrm{T}_{1}$ seed were germinated on kanamycin $\left(300 \mathrm{mg} \mathrm{liter}^{-1}\right)$ to determine from the segregation ratio the number of neomycin phosphotransferase II transgenes present. Kanamycin-resistant $T_{1}$ plants were transferred to soil and the phenotype following TaMV challenge was observed.

Run-off transcription. ${ }^{32} \mathrm{P}$-labeled run-off transcripts (Beck et al. 1994) were prepared from RAT and uninfected leaves of transgenic UT-II plants. For nuclear run-off analysis, nuclei from $10 \mathrm{~g}$ of leaf tissue (midribs removed) were isolated and used to produce ${ }^{32} \mathrm{P}$-labeled transcripts. Labeled transcripts were prepared by the modifications of the protocol of Cox and Goldberg (1988) and hybridized to denatured plasmid DNA bound to nylon membranes (Hybond $\mathrm{N}+$ ). The denatured DNA (5 $\mu \mathrm{g}$ per slot) consisted of bacteriophage lambda, pUC 19 cloning vector, an Arabidopsis thaliana actin clone, pAtc-4
(Nairn et al. 1988), a tomato (Lycopersicon esculentum) cyclophilin cDNA clone, pMON8635 (Gasser et al. 1990), a tomato ubiquitin gene ubi3 (Hoffman et al. 1991), and clones of the two transgenes, TaMV-CP (pC25; Eagles et al. 1990) and kanamycin resistance (pART27; Gleave 1992).

Biolistics. Fully expanded leaves from 6-week-old plants were surface sterilized, in ethanol and commercial bleach, rinsed six times in sterile distilled water, and subsequently bombarded with $0.6-\mu \mathrm{m}$ gold particles coated with $1 \mu \mathrm{g}$ of DNA from different constructs. Coating of the gold particles with DNA was performed according the protocol described for the Biolistic PDS-1000/He Particle Delivery System (Bio-Rad Laboratories, Richmond, CA). Forty-eight hours after bombardment, the leaves were immersed for $24 \mathrm{~h}$ in a $50 \mathrm{mM}$ sodium phosphate solution ( $\mathrm{pH}$ 7.0) containing $1 \mathrm{mM} \mathrm{X-Gluc} \mathrm{and}$ $1 \mathrm{mM}$ EDTA. Chlorophyll was removed by placing the bombarded leaves in $70 \%$ ethanol for 24 to 48 h (Hobbs et al. 1993).

\section{Subcloning of TaMV-CP fragments into the WCIMV vector.}

Subcloning and PCR were performed by standard techniques (Sambrook et al. 1989). The different fragments of the TaMV-CP gene introduced into $7 \mathrm{~K}^{*}$ were produced by PCR using oligonucleotides pairs CP1, 5'-AAT TGT CGA CAG GCT GGA ACC CTT and CP2, 5'-AAT TGT CGA CTT CGT GGG TGG CTC (W-TaMV\#1); CP3, 5'-AAT TGT CGA CCA GTA CCA CGC TTA and CP4, 5'-AAT TGT CGA CCA TGG GTT TAA GTG (W-TaMV\#2); CP5, 5'-AAT TGT CGA CGA GCC ACC CAC GAA and CP6, 5'-AAT TGT CGA CGC GTT GTA AAC CAT (W-TaMV\#3); CP7, 5'-AAT TGT CGA CCA TCT CCT GAC ATA and CP8, 5'-AAT TGT CGA CCG AAT TCT TCA GCG (W-TaMV\#4); CP9, 5'-AAT TGT CGA CGT GCG CTC GCA GAG and CP10, 5'-AAT TGT CGA CTT ACA CCC CCT TCA (W-TaMV\#5); CP11, 5'-AAT TGT CGA CCG CTG AAG AAT TCG and CP12, 5'-AAT TGT CGA CCC CTG ACA GTT GAA (W-TaMV\#6). Fragments TaMV\#5a, \#5b, and \#6 were amplified using a combination of existing oligonucleotides (CP9/CP8, CP11/CP10, and CP11/CP12, respectively) (Fig 1B).

Transcription and plant inoculation. SalI-digested DNA (1 $\mu \mathrm{g}$ ) from the W-TaMV constructs was used for transcription reactions using an AmpliScribe high-yield transcription kit following the manufacturer's instructions (Epicenter Technologies, Madison, WI). The transcription products were analyzed by agarose gel electrophoresis and RNAs were inoculated manually onto two carborundum-dusted $N$. benthamiana leaves as previously described (Beck et al. 1994). For TaMV co-inoculations, sap was prepared from TaMV-infected $N$. benthamiana leaves and diluted in water.

Northern hybridizations. Plant tissue was ground under liquid nitrogen and total RNA extractions were performed using Triazol reagent following the manufacturer's instructions (Life Technologies, Rockville, MD, U.S.A.). Electrophoresis of $5 \mu \mathrm{g}$ (transgene mRNA levels studies) or $0.5 \mu \mathrm{g}$ (from virus-infected plants) of total RNA was performed in formaldehyde denaturing agarose gels (Sambrook et al. 1989). After capillary transfer of the RNAs to N-hybond membranes (Amersham Pharmacia Biotech, Little Chalfont, Buckinghamshire, U.K.), the membranes were hybridized with ${ }^{32} \mathrm{P}$-labeled TaMV-CP- or WCIMV-CPspecific random primer probes (Rediprime II, Amersham Pharmacia Biotech). Prehybridization (2 h) and hybridization (12 h) steps were performed with Church buffer $(0.5 \mathrm{M}$ sodium phosphate, $\mathrm{pH} 7.2,7 \%$ sodium dodecyl sulfate, $1 \mathrm{mM} \mathrm{Na} 2$ EDTA) at 50 and $60^{\circ} \mathrm{C}$ degrees, respectively (Church and Gilbert 1984). Unbound probe was removed by low and high stringency washes at $65^{\circ} \mathrm{C}$ degrees (Amersham Pharmacia Biotech). The membranes were exposed to film for 2 or $12 \mathrm{~h}$. 
RT-PCR. Poly-A RNAs were extracted using a Dyna-beads oligo-dT kit (Dynal Pty Ltd, Carlton, Victoria, Australia) following the manufacturer's instructions except that the initial amount of plant tissue and corresponding reaction volumes were scaled down 10-fold. The leaf samples $(10 \mathrm{mg})$ were taken from two opposite leaves from the inoculated or upper leaves. The RT-PCR reactions were performed using the SuperScript One-Step RT-PCR system (Life Technologies) in a final volume of $12 \mu \mathrm{l}$, and were carried out in a Techne Genius PCR machine $\left(30 \mathrm{~s}\right.$ at $94^{\circ} \mathrm{C}, 45 \mathrm{~s}$ at $55^{\circ} \mathrm{C}, 1 \mathrm{~min} 45 \mathrm{~s}$ at $70^{\circ} \mathrm{C}$

A

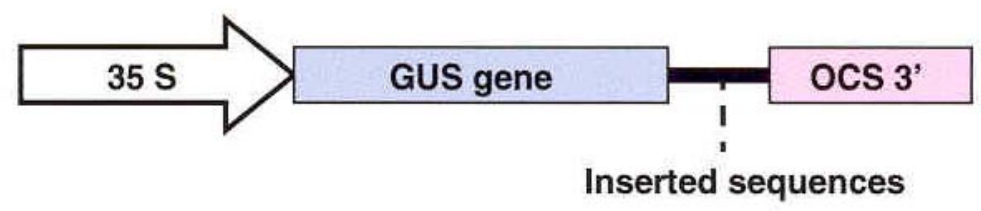

B

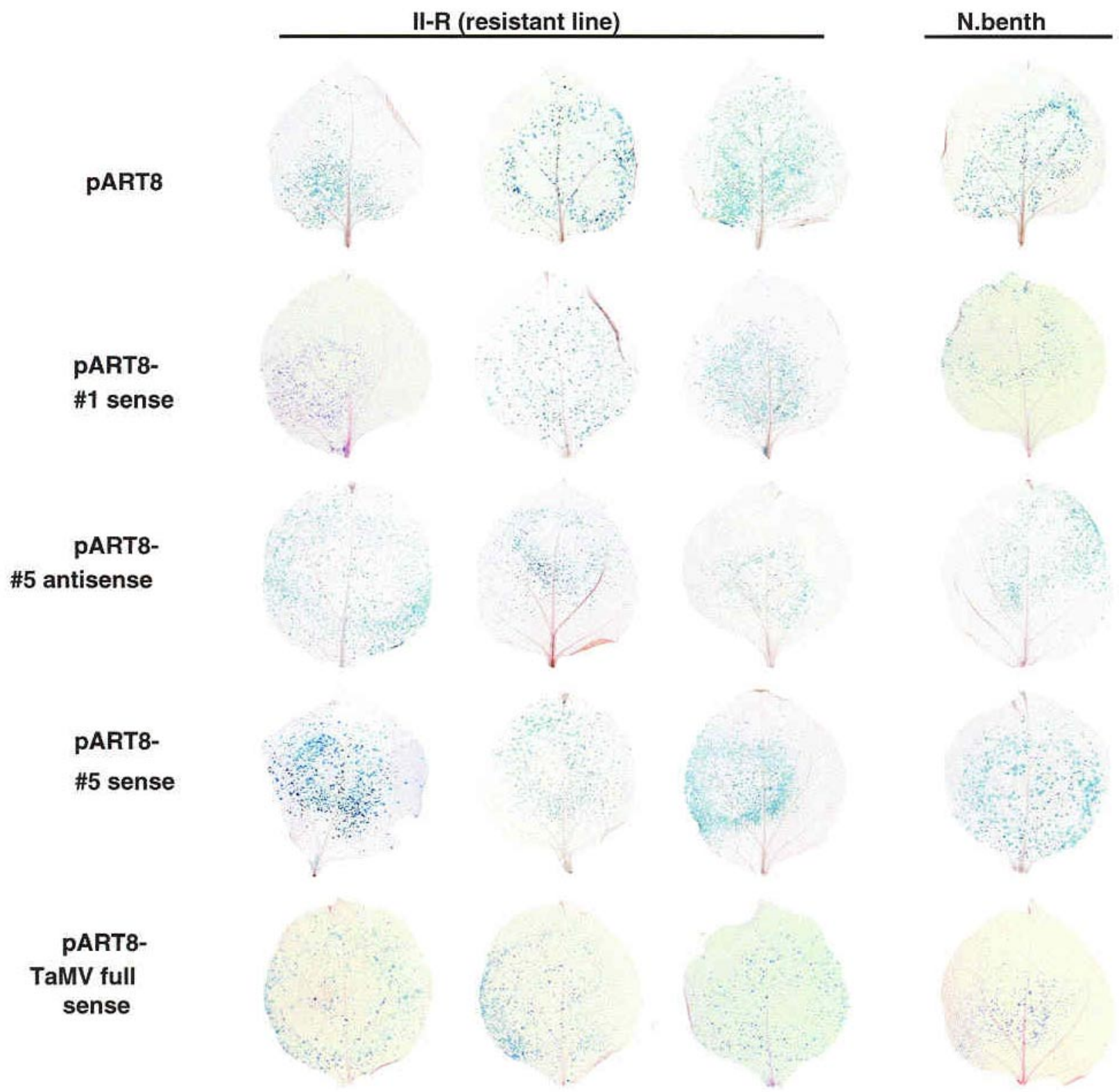

Fig. 6. GUS expression is not reduced by post-transcriptional gene silencing (PTGS), following bombardment of GUS-Tamarillo mosaic virus coat protein (TaMV-CP) sequences into resistant plants. A, The vector pART8, containing the GUS gene under the control of the CaMV $35 \mathrm{~S}$ promoter was used for transient expression assays. TaMV-CP sequences were introduced downstream of the GUS gene in the sense or antisense orientation. B, Leaves from the transgenic line II-R and nontransgenic plants were bombarded with gold particles coated with DNA from the respective plasmids. After bombardment, the leaves were kept in the dark for $48 \mathrm{~h}$, then histochemically stained for GUS activity. Shown are typical results obtained in four experiments ( $>40$ bombarded leaves per construct). 
for 30 cycles). The oligonucleotide pair CV7 (5'-GCT TCT GTT GAA ATC TCA GGT TGC-3') and CV8 (5'-ATG TCT GTC AAG GAT GGA GGA GTG-3') were complementary to sequences of the $7 \mathrm{~K}$ and $\mathrm{CP}$ genes of WCIMV, respectively. The plasmid $\mathrm{pC} 25$, containing the full-length TaMV-CP (Eagles et al. 1990), was used as DNA template in all TaMVCP PCR amplifications.

\section{ELISA.}

ELISA analysis (Clark and Adams 1977) involved WCIMV$\mathrm{O}$ anti-CP polyclonal antibodies from New Zealand White rabbits previously injected with purified WCIMV-O virions (Beck et al. 1994). Plants showing ELISA readings above 0.144 (mean value of all negative controls plus three standard deviations) were scored as infected.

\section{LITERATURE CITED}

Anandalakshmi, R., Pruss, G. J., Ge, X., Marathe, R., Mallory, A. C., Smith, T. H., and Vance, V. B. 1998. A viral suppressor of gene silencing in plants. Proc. Natl. Acad. Sci. U.S.A. 95:13079-13084.

Angell, S. M., and Baulcombe D. C. 1997. Consistent gene silencing in transgenic plants expressing a replicating potato virus X RNA. EMBO (Eur. Mol. Biol. Organ.) J. 16:3675-3684.

Baulcombe, D. C. 1999. Viruses and gene silencing in plants Arch. Virol. 15:189-201.

Beck, D. L., Guilford P. J., Voot D. M., Andersen M. T., and Forster R. L. 1991. Triple gene block proteins of white clover mosaic potexvirus are required for transport. Virology 183:695-702.

Beck, D. L., Van Dolleweerd, C. J., Lough, T. J., Balmori, E., Voot, D. M., Andersen, M. T., O’Brien, I. E., and Forster, R. L. 1994. Disruption of virus movement confers broad-spectrum resistance against systemic infection by plant viruses with a triple gene block. Proc. Natl. Acad. Sci. U.S.A. 91:10310-10314.

Benfey, P. N., and Chua, N. H. 1989. Regulated genes in transgenic plants. Science 244:174-181.

Bernstein, E., Caudy, A. A., Hammond, S. M., and Hannon, G. J. 2001. Role for a bidentate ribonuclease in the initiation step of RNA interference. Nature 409:363-366

Brigneti, G., Voinnet, O., Li, W. X., Ji, L. H., Ding, S. W., and Baulcombe, D. C. 1998. Viral pathogenicity determinants are suppressors of transgene silencing in Nicotiana benthamiana. EMBO (Eur. Mol. Biol. Organ.). 17:6739-6746.

Canto, T., and Palukaitis, P. 1998. Transgenically expressed cucumber mosaic virus RNA 1 simultaneously complements replication of cucumber mosaic virus RNAs 2 and 3 and confers resistance to systemic infection. Virology 250:325-336.

Carr, J. P., Gal-On, A., Palukaitis, P., and Zaitlin, M. 1994. Replicasemediated resistance to cucumber mosaic virus in transgenic plants involves suppression of both virus replication in the inoculated leaves and long-distance movement. Virology 199:439-447.

Church, G. M., and Gilbert, W. 1984 Genomic sequencing. Proc. Natl. Acad. Sci. U.S.A. 81:1991-1995.

Clark, M. F., and Adams, A. N. 1977. Characteristics of the microplate method of enzyme-linked immunosorbent assay for the detection of plant viruses. J. Gen. Virol. 34:475-483.

Cox, K. H., and Goldberg, R. B. 1988. Analysis of plant gene expression. Pages 1-35 in: Plant Molecular Biology, A Practical Approach. C. H. Shaw, ed. IRL Press, Washington, D.C.

Dalmay, T., Hamilton, A., Mueller, E., and Baulcombe, D. C. 2000. Potato virus $\mathrm{X}$ amplicons in Arabidopsis mediate genetic and epigenetic gene silencing. Plant Cell. 12:369-379.

de Carvalho, F., Gheysen, G., Kushnir, S., van Montagu, M., Inze, D., and Castresana, C. 1992. Suppression of beta-1,3-glucanase transgene expression in homozygous plants. EMBO (Eur. Mol. Biol. Organ.). 11:2595-2602.

Ding, X. S., Shintaku, M. H., Arnold, S. A., and Nelson, R. S. 1995. Accumulation of mild and severe strains of tobacco mosaic virus in minor veins of tobacco. Mol. Plant-Microbe Interact. 8:32-40.

Dougherty, W. G., and Carrington, J. C. 1988. Expression and function of potyvirus gene products. Annu. Rev. Phytopathol. 26:123-143.

Dougherty, W. G., Lindbo, J. A., Smith, H. A., Parks, T. D., Swaney, S., and Proebsting, W. M. 1994. RNA-mediated virus resistance in transgenic plants: Exploitation of a cellular pathway possibly involved in RNA degradation. Mol. Plant-Microbe Interact. 7:544-552.

Eagles, R. M., Gardner, R. C., and Forster, R. L. 1990. Nucleotide sequence of the Tamarillo mosaic virus $\mathrm{CP}$ gene. Nucleic Acids Res.
18:7166.

Elkind, Y., Edwards, R., Mavandad, M., Hedrick, S. A., Ribak, O., Dixon, R. A., and Lamb, C. J. 1990. Abnormal plant development and downregulation of phenylpropanoid biosynthesis in transgenic tobacco containing a heterologous phenylalanine ammonia-lyase gene. Proc. Natl. Acad. Sci. U.S.A. 87:9057-9061.

English, J. J., Davenport, G. F., Elmayan, T., Vaucheret, H., and Baulcombe, D. C. 1997. Requirement of sense transcription for homology-dependent virus resistance and trans-inactivation. Plant J. 12:597603.

English, J. J., Mueller, E., and Baulcombe, D. C. 1996. Suppression of virus accumulation in transgenic plants exhibiting silencing of nuclear genes. Plant Cell. 8:179-188.

Forster, R. L., Beck, D. L., Guilford, P. J., Voot, D. M., Van Dolleweerd, C. J., and Andersen, M. T. 1992. The CP of white clover mosaic potexvirus has a role in facilitating cell-to-cell transport in plants. Virology 191:480-484.

Gasser, C. S., Gunning, D. A., Budelier, K. A., and Brown, S. M. 1990. Structure and expression of cytosolic cyclophilin/peptidyl-prolyl cistrans isomerase of higher plants and production of active tomato cyclophilin in Escherichia coli. Proc. Natl. Acad. Sci. U.S.A. 87:9519-9523.

Gleave, A. P. 1992. A versatile binary vector system with a T-DNA organizational structure conducive to efficient integration of cloned DNA into the plant genome. Plant Mol. Biol. 20:1203-1207.

Goodwin, J., Chapman, K., Swaney, S., Parks, T. D., Wernsman, E. A., and Dougherty, W. G. 1996. Genetic and biochemical dissection of transgenic RNA-mediated virus resistance. Plant Cell. 8:95-105.

Hamilton, A. J., and Baulcombe, D. C. 1999. A species of small antisense RNA in posttranscriptional gene silencing in plants. Science 286:950952.

Hellwald, K. H., and Palukaitis, P. 1995. Viral RNA as a potential target for two independent mechanisms of replicase-mediated resistance against cucumber mosaic virus. Cell 83:937-946.

Hobbs, S. L. A., Warkentin, T. D., and DeLong, C. M. O. 1993. Transgene copy number can be positively or negatively associated with transgene expression. Plant Mol. Biol. 21:17-26.

Hoekema, A., Hirsch, P. R., Hooykaas, P. J. J, and Schilperoort, R. A 1983. A binary plant vector strategy based on separation of vir- and T-region of the Agrobacterium tumefaciens Ti-plasmid. Nature 303:179-180

Hoffman, N. E., Ko, K., Milkowski, D., and Pichersky, E. 1991. Isolation and characterization of tomato cDNA and genomic clones encoding the ubiquitin gene ubi3. Plant Mol. Biol. 17:1189-1201.

Horsch, R. B., Fry, R. T., Hoffmann, N. L., Eichholtz, D., Rogers, S. G., and Fraley, R. T 1987. A simple and general method for transferring genes into plants. EMBO (Eur. Mol. Biol. Organ.) J. 6:3901-3907

Iyer, L. M., and Hall, T. C. 2000. Virus recovery is induced in Brome mosaic virus p2 transgenic plants showing synchronous complementation and RNA-2-specific silencing. Mol. Plant-Microbe Interact. 13:247-258.

Jefferson, R. A., Kavanagh, T. A., and Bevan, M. W. 1987. GUS fusions: Beta-glucuronidase as a sensitive and versatile gene fusion marker in higher plants. EMBO (Eur. Mol. Biol. Organ.) J. 6:3901-3907.

Kasschau, K. D., and Carrington, J. C. 1998. A counterdefensive strategy of plant viruses: Suppression of posttranscriptional gene silencing. Cell 95:461-470.

Kjemtrup, S., Sampson, K. S., Peele, C. G., Nguyen, L. V., Conkling, M. A., Thompson, W. F., and Robertson, D. 2000. Gene silencing from plant DNA carried by a geminivirus. Plant J. 14:91-100.

Kooter, J. M., Matzke, M. A., and Meyer, P. 1999. Listening to the silent genes: Transgene silencing, gene regulation and pathogen control. Trends Plant Sci. 4:340-347

Lindbo, J. A., and Dougherty, W. G. 1992a. Pathogen-derived resistance to a potyvirus: Immune and resistant phenotypes in transgenic tobacco expressing altered forms of a potyvirus coat protein nucleotide sequence. Mol. Plant-Microbe Interact. 5:144-153.

Lindbo, J. A., and Dougherty, W. G. 1992b. Untranslatable transcripts of the tobacco etch virus coat protein gene sequence can interfere with tobacco etch virus replication in transgenic plants and protoplasts. Virology 189:725-733.

Lindbo, J. A., Silva-Rosales, L., Proebsting, W. M., and Dougherty, W. G. 1993. Induction of a highly specific antiviral state in transgenic plants for regulation of gene expression and virus resistance. Plant Cell 5:1749-1759.

Longstaff, M., Brigneti, G., Boccard, F., Chapman, S., and Baulcombe, D. C. 1993. Extreme resistance to potato virus $\mathrm{X}$ infection in plants expressing a modified component of the putative viral replicase. EMBO (Eur. Mol. Biol. Organ.) J. 12:379-386.

Lutcke, H. A., Chow, K. C., Mickel, F. S., Moss, K. A. , Kern, H. F., and Scheele, G. A. 1987. Selection of AUG initiation codons differs in plants and animals. EMBO (Eur. Mol. Biol. Organ.) J. 6:43-48.

Mäki-Valkama, T., Valkonen, J. P. T., Kreuze, J. F., and Pehu, E. 2000 
Transgenic resistance to $\mathrm{PVY}(\mathrm{O})$ associated with post-transcriptional silencing of $\mathrm{P} 1$ transgene is overcome by $\mathrm{PVY}(\mathrm{N})$ strains that carry highly homologous $\mathrm{P} 1$ sequences and recover transgene expression at infection. Mol. Plant-Microbe Interact. 13:366-373.

Mallory, A. C., Ely, L., Smith, T. H., Marathe, R., Anandalakshmi R., Fagard, M., Vaucheret, H., Pruss, G., Bowman, L, and Vance, V. B. 2001. HC-Pro suppression of transgene silencing eliminates the small RNAs but not transgene methylation or the mobile signal. Plant Cell. $13: 571-583$

Marano, M. R., and Baulcombe, D. C. 1998. Pathogen-derived resistance targeted against the negative-strand RNA of tobacco mosaic virusRNA strand-specific gene silencing. Plant J. 13:537-546.

Marx, J. 2000. Interfering with gene expression. Science 288:1370-1372.

Mossop, D. W. 1977. Isolation, purification and properties of Tamarillo mosaic virus, a member of the potato virus Y group. N. Z. J. Agric. Res. 20:535-541.

Mueller, E., Gilbert, J., Davenport, G. , Brigneti, G., and Baulcombe, D. C. 1995. Homology-dependent resistance-Transgenic virus resistance in plants related to homology-dependent gene silencing. Plant J. 7:1001-1013.

Nairn, C. J., Winesett, L., and Ferl, R. J. 1988. Nucleotide sequence of an actin gene from Arabidopsis thaliana. Gene 65:247-257

Napoli, C., Lemieux, C., and Jorgensen, R. A. 1990. Introduction of a chimeric chalcone synthase gene into Petunia results in reversible co-suppression of homologous genes in trans. Plant Cell 2:279-289.

Palauqui, J. C., and Balzergue, S. 1999. Activation of systemic acquired silencing by localized introduction of DNA. Curr. Biol. 9:59-66.

Palauqui, J. C., Elmayan, T., Pollien, J. M., and Vaucheret, H. 1997. Systemic acquired silencing: Transgene-specific post-transcriptional silencing is transmitted by grafting from silenced stocks to non-silenced scions. EMBO (Eur. Mol. Biol. Organ.) J. 16:4738-4745.

Puurand, U., Makinen, K., Paulin, L., and Saarma, M. 1994. The nucleotide sequence of potato virus A genomic RNA and its sequence similarities with other potyviruses. J. Gen. Virol. 75:457-461.

Ruiz, M. T., Voinnet, O., and Baulcombe, D. C. 1998. Initiation and maintenance of virus-induced gene silencing. Plant Cell 10:937-946.

Sambrook, J., Maniatis, T., and Fitch, E. F. 1989. Molecular Cloning: A Laboratory Manual. Cold Spring Harbor Laboratory Press, Plainview, NY, U.S.A.

Sijen, T., and Kooter, J. M. 2000. Post-transcriptional gene-silencing: RNAs on the attack or on the defense? Bioessays 22:520-531.

Sijen, T., Wellink, J., Hendriks, J., Verver, J., and Vankammen, A. 1995 Replication of cowpea mosaic virus Rna1 or Rna2 is specifically blocked in transgenic Nicotiana benthamiana plants expressing the fulllength replicase or movement protein genes. Mol. Plant-Microbe Interact. 8:340-347

Sijen, T., Wellink, J., Hiriart, J. B., and Vankammen, A. 1996. RNA-mediated virus resistance-role of repeated transgenes and delineation of targeted regions. Plant Cell 8:2277-2294.

Smith, H. A., Swaney, S. L., Parks, T. D., Wernsman, E. A., and Dougherty, W. G. 1994. Transgenic plant virus resistance mediated by untranslat- able sense RNAs: Expression, regulation, and fate of nonessential RNAs. Plant Cell 6:1441-1453.

Sonoda, S., Mori, M., and Nishiguchi, M. 1999. Homology-dependent virus resistance in transgenic plants with the coat protein gene of sweet potato feathery mottle potyvirus: Target specificity and transgene methylation. Phytopathology 89:385-391.

Tanzer, M. M., and Meagher, R. B. 1994. Faithful degradation of soybean rbcS mRNA in vitro. Mol. Cell Biol. 14:2640-2650.

Tanzer, M. M., Thompson, W. F., Law, M. D., Wernsman, E. A., and Uknes, S. 1997. Characterization of post-transcriptionally suppressed transgene expression that confers resistance to tobacco etch virus infection in tobacco. Plant Cell 9:1411-1423.

Tenllado, F., Garcia-Luque, I., Serra, M. T., and Diaz-Ruiz, J. R. 1995. Nicotiana benthamiana plants transformed with the 54-kDa region of the pepper mild mottle tobamovirus replicase gene exhibit two types of resistance responses against viral infection. Virology 211:170-183.

Thomas, C. L., Jones, L., Baulcombe, D. C, and Maule, A. J 2001. Size constraints for targeting post-transcriptional gene silencing and for RNA-directed methylation in Nicotiana benthamiana using a potato virus X. Plant J. 25:417-425

Thompson, D. M., Tanzer, M. M., and Meagher, R. B. 1992. Degradation products of the mRNA encoding the small subunit of ribulose- 1,5bisphosphate carboxylase in soybean and transgenic petunia. Plant Cell 4:47-58.

van der Krol, A. R., Mur, L. A., Beld, M., Mol, J. N., and Stuitje, A. R. 1990. Flavonoid genes in petunia: Addition of a limited number of gene copies may lead to a suppression of gene expression. Plant Cell 2:291 299.

Vaucheret, H., Nussaume, L. , Palauqui, J. C., Quillere, I., and Elmayan, T. 1997. A transcriptionally active state is required for post-transcriptional silencing (cosuppression) of nitrate reductase host genes and transgenes. Plant Cell 9:1495-1504.

Voinnet, O., and Baulcombe, D. C. 1997. Systemic signaling in gene silencing. Nature 389:553.

Voinnet, O., Lederer, C., and Baulcombe, D. C. 2000. A viral movement protein prevents spread of the gene silencing signal in Nicotiana benthamiana. Cell 103:157-167.

Voinnet, O., Pinto, Y. M., and Baulcombe, D. C. 1999. Suppression of gene silencing: A general strategy used by diverse DNA and RNA viruses of plants. Proc. Natl. Acad. Sci. U.S.A. 96:14147-14152

Voinnet, O., Vain, P., Angell, S., and Baulcombe, D. C. 1998. Systemic spread of sequence-specific transgene RNA degradation in plants is initiated by localized introduction of ectopic promoterless DNA. Cell 95:177-187.

Wintermantel, W. M., Banerjee, N., Oliver, J. C., Paolillo, D. J., and Zaitlin, M. 1997. Cucumber mosaic virus is restricted from entering minor veins in transgenic tobacco exhibiting replicase-mediated resistance. Virology 231:248-257.

Zamore, P. D., Tuschl, T., Sharp, P. A., and Bartel, D. P. 2000. RNAi: Double-stranded RNA directs the ATP-dependent cleavage of mRNA at 21 to 23 nucleotide intervals. Cell 101:25-33. 